\title{
How Saucy did it Make the Poor? The Straw Plait and Hat Trades, Illegitimate Fertility and the Family in Nineteenth-Century Hertfordshire
}

\author{
NIGEL GOOSE \\ University of Hertfordshire
}

\begin{abstract}
The straw plait and hat industry provided considerable employment for women and children in south and west Hertfordshire in the nineteenth century, but was absent in much of the north and east. Many contemporaries felt it had a deleterious effect upon morality and the stability of the family, and its regional specificity within Hertfordshire allows these propositions to be tested through a comparative analysis of illegitimacy and examination of the family circumstances of young straw workers. It is discovered that illegitimacy ratios often give a misleading impression, failing to take into account the size of the population 'at risk', while illegitimacy rates suggest only minor differences between straw and non-straw areas, a more noticeable feature of the data being the generally higher illegitimacy rates found in Hertfordshire's small towns. Nor does the evidence suggest that the industry led to early break up of families. The rise and decline of illegitimacy in England between the late eighteenth and late nineteenth centuries presents a continuing conundrum, and while the growth and decay of the straw industry offers little explanatory value, this article suggests that the changing conditions in the agricultural labour market may have more relevance to counties such as Hertfordshire.
\end{abstract}

'The farmers complain of it, as doing mischief, for it makes the poor saucy, and no servants can be procured, where this manufacture establishes itself.' (Arthur Young, 1804). ${ }^{1}$

The straw plait and hat trades were of considerable importance to the economies of Hertfordshire and Bedfordshire, and to parts of Buckinghamshire, Essex and Suffolk, in the nineteenth century. ${ }^{2}$ Straw plaiting and hat making was already established in the seventeenth century, grew in the eighteenth, benefited prodigiously from the 
embargo on imported straw during the Napoleonic Wars, and continued to thrivedespite periodic setbacks - into the third quarter of the nineteenth century. The industry developed rapidly in the 1840 s, perhaps in response to the agricultural depressions that afflicted the start and end of that decade, but expansion continued after 1851. Far from disappearing as mechanization took hold towards the midnineteenth century and England became the 'workshop of the world', straw plait and hat making did not reach its peak until 1871, by when it employed 12,804 adults and children in Hertfordshire, 94 per cent of them female. From the 1870s the import of cheap straw plait from Japan and China signaled the demise of the plaiting trade and, although straw hat making held on better than plaiting, the impact was dramatic. In Hertfordshire the number of female plaiters almost halved in the 1870 s, and halved again in the 1880s, wages plummeting simultaneously. By 1901 numbers employed in the county had fallen to just 2,342 and in 1910 Mr Maberly Phillips could write of Hertfordshire in The Connoisseur, that 'only a few veterans of the art are left', by which time the rewards were derisory. ${ }^{3}$

In Hertfordshire the industry was heavily concentrated in the south west of the county. ${ }^{4}$ It was in fact only prominent in four of the twelve Superintendent Registrar's Districts (hereafter SRDs) situated within or across the boundary of the ancient county-Berkhamsted, St Albans, Hemel Hempstead and Hitchin. ${ }^{5}$ This concentration is reflected in the extent of female and child employment across the county, for among adults plaiting was very predominantly a female pursuit while providing extensive employment for children of both sexes. ${ }^{6}$ Edwin Grey in his reminiscences of Harpenden in the 1860 s recorded that 'The children, both boys and girls, learned to 
Table 1 : Employment in the Straw Industry in Hertfordshire in 1851

\begin{tabular}{|c|c|c|c|c|c|c|c|}
\hline \multirow[t]{2}{*}{ SRD } & \multicolumn{3}{|c|}{ Population } & \multirow{2}{*}{$\begin{array}{l}\text { Sex } \\
\text { Ratio }\end{array}$} & \multicolumn{3}{|c|}{$\begin{array}{c}\text { Percentage of } \\
\text { Occupied } \\
\text { Population in Straw }\end{array}$} \\
\hline & Total & $\mathrm{M}$ & $\mathrm{F}$ & & All & $\mathrm{M}$ & $\mathrm{F}$ \\
\hline Berkhamsted & 11,532 & 5,466 & 6,066 & 90 & 32 & 8 & 62 \\
\hline St Albans & 17,991 & 8,591 & 9,400 & 91 & 24 & 4 & 49 \\
\hline Hemel Hempstead & 13,094 & 6,325 & 6,769 & 93 & 29 & 8 & 59 \\
\hline Hitchin & 24,519 & 12,049 & 12,470 & 97 & 22 & 4 & 56 \\
\hline Hatfield \& Welwyn & 8,484 & 4,330 & 4,154 & 104 & 8 & 0 & 27 \\
\hline Royston & 14,481 & 7,375 & 7,106 & 104 & 4 & 0 & 18 \\
\hline Watford & 18,747 & 9,232 & 9,515 & 97 & 4 & 0 & 13 \\
\hline Hertford & 14,517 & 7,316 & 7,201 & 102 & 2 & 0 & 8 \\
\hline Ware & 16,445 & 8,323 & 8,122 & 102 & 0 & 0 & 1 \\
\hline Bishops Stortford & 13,074 & 6,500 & 6,574 & 99 & 0 & 0 & 1 \\
\hline Edmonton & 4,815 & 2,379 & 2,436 & 98 & 0 & 0 & 1 \\
\hline Barnet & 5,675 & 2,902 & 2,773 & 105 & 1 & 0 & 4 \\
\hline Hertfordshire & 163,374 & 80,788 & 82,586 & 98 & 13 & 2 & 35 \\
\hline
\end{tabular}

Note: Areas included in this table are only those that lay within the ancient county. Source: Digitized Hertfordshire Census Enumerators' Books, 1851.

plait when very young', and that although 'some of the men and the lads

were also good at the work, doing it at odd times, or in the evening after farm work... this home industry was always looked upon really as women's work', and at the age of nine or ten most boys took up employment with local farmers. ${ }^{7}$ These features are reflected in the proportions of the male and female occupied populations employed in the industry shown in Table 1, which has been constructed from a digitized database of the Census Enumerators' Books (hereafter CEBs) for the entire ancient county.

Where the industry thrived it made a significant contribution to family earnings. Young recorded the high wages paid in 1804-21 shillings per week at Redbourn, 14-18 shillings at Berkhamsted, and 5 shillings per day in St Albans - and, while commenting upon farmers' complaints about competition for labour, he also 
appreciated it was 'without any doubt of very great use to the poor, and has had a considerable effect in keeping down [poor] rates, which would have been far more burthensome without it'. ${ }^{8}$ Cobbett was a great champion of the industry, describing it in Cottage Economy (1824) as 'of all employments, the best suited to the wives and children of country labourers', and an ideal replacement for the domestic employment lost as a consequence of mechanization of textile production. ${ }^{9}$ Wages fell rapidly from the heights achieved during the Napoleonic Wars once the import of Italian plait and hats resumed, but from the 1820s the English industry started to exert itself and to provide considerable, if more modest, earnings. Despite periodic slumps when wages fell sharply, such as in 1832-4 and 1843, contemporary testimony indicates they remained substantial into the 1860 s at least. The most comprehensive report was that of A.J. Tansley, a prominent Luton hat manufacturer, published in 1860. Tansley's view was that from plaiting straw 'a well ordered family will obtain as much or more than the husband who is at work on the neighbouring farm', a view echoed in Grey's reminiscences of Harpenden, while women employed in hat manufactories could earn even more, up to $16-20$ shillings per week for 'the best fancy hands' ${ }^{10}$ Furthermore, both Tansley and Grey reported that plait was made all year round, with only a significant interruption during the gleaning season at harvest time, a view endorsed by the Poor Law Commissioners in their report of 1834, while Bedfordshire hat makers reported only very temporary interruptions to their activities in June or July. ${ }^{11}$ And if the specialized 'fancy straw weaving' at St Albans was 'only carried on for about two months of the year', it was noted that for the rest of the year the women involved 'work at straw plait'. ${ }^{12}$ It may not be coincidental that in his travels through the heart 
of the straw plait country in 1822 - from St Albans to Redbourn, from Redbourn to Hemel and from Hemel to Chesham — Cobbett recorded that 'I never saw the country children better clad, or look cleaner and fatter than they look here...' ${ }^{13}$

\section{II}

Other observers, however, were quick to condemn the trade on moral grounds. It was not unusual for contemporaries to express reservations about occupations that gave opportunities for young people-young women in particular- to achieve financial independence, nor was it unusual for them to complain of occupations that allowed young men and women to work in close proximity. Straw plaiting was, however, particularly frequently condemned, eliciting extremely severe judgments. The Clergy Visitation Returns for Buckinghamshire in 1854 and 1866 blamed high levels of illegitimacy squarely on the industry, at Stewkley and Linsdale the 'evils' of the trade were castigated, while at Aston Clinton the local clergyman complained that plaiters became independent of their parents too soon, leading to early marriages and unspecified 'immorality' which, it was claimed, frequently took place on Buckland Common. ${ }^{14}$ The Children's Employment Commission Report of 1843 also judged straw plaiters to be of low moral condition, Major Burns noting that 'Young persons of both sexes are engaged in it, and as in summer they take their work into the fields and congregate much together, the usual consequence of such intercourse ensues, and chastity is at a sad discount while prostitution is at a high premium.' This, he continued, 'was the opinion of every one I conversed with on the subject', including the Reverend Payne of Chesham, who complained that 'the religious and moral 
condition of some of the youths in this town is painfully distressing; fornication is lamentably frequent' among them, while the predisposition to harsh and unfounded judgments is revealed by the suggestion of Burns that the fondness of the young girls for fancy dress meant that they 'no doubt [sic] often resort to prostitution' as a means of enhancing their income. ${ }^{15}$ John Hodgson of Chesham, surgeon, felt 'The moral condition of the young people would appear to be injured by their early casting off the control of their parents' while 'The association of many such young persons together with no better example than that of their fellows before them, tends to the same effect', and Robert Merry, M.D., of Hemel Hempstead reported that straw plaiters there 'become generally squalid women, and many very immoral, making bad domestic servants'. ${ }^{16}$ In more general terms the report of a further Royal Commission on Children's Employment in 1864 claimed that if parents thought a child might earn 6 pence per week from plaiting straw they would put them to work, and hence 'It is not surprising ... that ignorance and vice abound among a population so reared' ${ }^{17}$ John Clegg, Rector of Toddington, was particularly severe, complaining of the 'baneful influence' of the industry upon children's education, the crowded and overheated conditions in the plait schools, and particularly the fact that the morals of the young men and women were 'at a very low ebb', with the result that 'A large average of the women have illegitimate children, and some at such an early age as to startle even those who are at home in criminal statistics'. ${ }^{18}$

George Culley's evidence to the Royal Commission on the Employment of Children, Young Persons and Women in Agriculture of 1867/8 similarly noted the 'great want of chastity amongst the plait girls' and returned to the dangers of young 
people consorting together, complaining that male and female plaiters 'go about the lanes together in summer engaged in work which has not even the wholesome corrective of more or less physical exhaustion', showing a remarkable preference for child fatigue over potential moral laxity. ${ }^{19}$ Most of the evidence upon which Culley relied came from clergymen, but Mr Thomas Magor of Toddington, a layman, also felt the industry was 'the primary cause of the peculiar wretchedness of this district'. His concern was not with promiscuity, however, but with 'the fact of the girls being engrossed from early childhood by plaiting, they grow up as a class very ignorant of domestic economy, they can neither cook, make or mend their clothes, which are usually bought of some material which will not wash, and is worn until it drops to pieces'. ${ }^{20}$

The validity of these remarks are difficult to judge, for historical evidence produced to date regarding the extra-marital sexual activities of women in the straw plait districts is very slim. Writing in 1942, Dony provided data on illegitimacy in Bedfordshire in 1865 , finding an illegitimacy rate of 78 per 1,000 there compared with 62 in the country as a whole. In the Bedford Union, where there was no plaiting, the rate stood at 62 per 1,000, but in the plaiting unions of Leighton Buzzard, Ampthill, Biggleswade, Luton and Woburn it stood at 65, 70, 83, 93 and 100 respectively. From this he concluded that 'there was some justification for the allegations'. ${ }^{21}$ Gróf's analysis of baptism registers for Edlesborough in Buckinghamshire between 1800 and 1899, however, reveals modest illegitimacy ratios and, finding few child brides or bridal pregnancies either, he concluded that 'the alleged promiscuity of the straw plait girls was never widespread in the parish of 
Edlesborough'. ${ }^{22}$ What little research has been completed to date on the issue, therefore, is highly localized, and draws contradictory conclusions.

\section{III}

There is a dearth of research on illegitimacy in nineteenth-century England, particularly at the regional and local level. ${ }^{23}$ The national picture as currently understood, from parish register evidence before 1837 and civil registration data thereafter, is that illegitimacy rose almost threefold across the eighteenth century to peak in the1820s, fell back, then rose again from the 1830 s to reach new heights by mid-century, after which it went into a long-term decline that was not reversed until the $1940 \mathrm{~s} .{ }^{24}$ What caused the eighteenth-century rise is disputed, although most recent interpretations emphasize socio-economic factors rather than changing sexual practices. $^{25}$ The decline of illegitimacy in the second half of the nineteenth century, however, finds no clear socio-economic cause, and historians generally offer explanations which encompass declining marital fertility as well. ${ }^{26}$ There was a distinctive regional pattern to illegitimacy which had deep historical roots in changing courtship and marriage practices. ${ }^{27}$ In the nineteenth century illegitimacy was highest in Cumbria (where it was also most widespread), in East Anglia (notably in Norfolk), in mid-Wales and in north and east Yorkshire, with other hotspots in Shropshire, Staffordshire and Nottinghamshire. ${ }^{28}$ Some historians have detected an association between agricultural employment and high levels of illegitimacy, others have suggested a relationship between illegitimacy and the level and persistence of service, while others still have posited a relationship between female employment and 
illegitimacy, mediated through the enhanced migratory movements that this employment entailed. ${ }^{29}$ The respective levels in town and countryside have produced conflicting interpretations, cases being made for both low and - regionally at leasthigh urban illegitimacy. ${ }^{30}$ Although illegitimacy rates fell everywhere in the second half of the nineteenth century and there was a high degree of persistence over time, counties such as Bedfordshire, Hertfordshire, Huntingdonshire and Rutland stand out as exceptions, leading Laslett to suggest that 'their strange-looking movement invites investigation'. 31

To examine these issues, before the 1840s historians can only rely upon parish register evidence to measure illegitimacy, counting the number of baptisms recorded as illegitimate and comparing them with total baptisms to construct an illegitimacy ratio. The reliability of the registers, in general and as a record of illegitimate births, and the representativeness of the sample if only Anglican registers are used, are causes for concern, particularly as levels of recording changed over time. ${ }^{32}$ But even with perfect data the illegitimacy ratio is a crude index, for it does not relate the number of illegitimate births to the population 'at risk' (never married, divorced or widowed women of child-bearing age), and might therefore be affected by the age, sex and marital composition of the population. Furthermore, unless illegitimate and legitimate births move in parallel, changing levels of marital fertility will also affect the ratio of illegitimate births. ${ }^{33}$ Historians have comforted themselves by claiming that such differences are unlikely to subvert broad, regional differences, or by arguing that where both rates and ratios can be calculated the basic trends are similar. ${ }^{34}$ For detailed studies at the local level, however, fertility rates — which compare the number 
of illegitimate births to the number of women at risk — are infinitely preferable to illegitimacy ratios.

The civil registration data published in the reports of the Registrar General of Births, Marriages and Deaths, allied to age and marital structure derived from decennial censuses, allows examination of levels of illegitimacy that avoid these drawbacks. Unfortunately, as they only record data for Registrar's Districts and subdistricts, they rarely allow examination of individual parishes, and hence cannot provide the depth of insight made possible by detailed, local studies employing nominal record linkage and parish register reconstitution. ${ }^{35}$ They do, however, provide not only a far better measure of illegitimacy, but also the opportunity to employ a consistent source to compare and contrast local patterns within and between counties without incurring the opportunity cost that time-consuming record linkage techniques entail. To date illegitimacy rates have only been systematically employed at county level for the years 1870-2, 1880-2, 1890-2 and 1900-02, and at Registration District (SRD) level for $1861 .{ }^{36}$ Here they will be calculated for Hertfordshire Registration Sub-Districts (RDs) where possible, using the digitized 1851 census for the county, and for Registration Districts (SRDS) where not, using age and marital structures derived from census reports, alongside the illegitimacy ratios for Registration SubDistricts, and in conjunction with data on general and marital fertility. The results generated will be considered in relation to the geographical concentration of the straw plait and hat trades, and the industry's progress over time, in an attempt to determine whether or not contemporary judgments on its influence upon illegitimacy were justified. 


\section{IV}

Table 2 presents the general, marital and illegitimate fertility rate for each of the twenty-eight Hertfordshire sub-districts in 1851, as well as their illegitimacy ratios, distinguishing areas where the straw industry was prominent, and also those districts which included one of the nine substantial towns identified in the 1851 census report. ${ }^{37}$ Before discussing these measures, it is worth noting that the illegitimacy data bears out some of the concerns expressed above about reliance upon illegitimacy ratios. The correlation coefficient between illegitimacy rates and ratios stands at 0.81 , suggesting a fairly strong positive association, but closer scrutiny of the data identifies particular problems. In Ware, for example, the ratio stood only slightly higher than the county average, but its illegitimacy rate was the second highest of all the RDs. By contrast in the St Albans district the ratio was easily the highest in the county, but the illegitimacy rate, while high, was only the sixth highest of the RDs. The explanation for these discrepancies lies in the age, sex and marital structure, and the levels of legitimate fertility, in these two districts. In Ware there was a balanced sex ratio (99 males per 100 females), a low ratio of single/widowed to married women aged 15-44 (87), and a marital fertility rate a little above the county average. In St Albans the sex ratio was heavily skewed towards women (91 males per 100 females), the ratio of single-widowed to married females ages 15-44 very high indeed (133), and marital fertility was very low. Together these features served to depress the illegitimacy fertility ratio in Ware, and to exaggerate it in St Albans, creating wholly false impressions of the tendency of the 'at risk' populations to produce illegitimate 
Table 2 : General, Marital and Illegitimate Fertility in Hertfordshire, 1847-55, by RD

\begin{tabular}{|c|c|c|c|c|c|c|c|c|}
\hline SRD & RD & $\begin{array}{l}\text { Straw } \\
\text { District }\end{array}$ & $\begin{array}{l}\text { Urban/ } \\
\text { Rural }\end{array}$ & $\begin{array}{l}\text { General } \\
\text { fertility } \\
\text { rate }(1)\end{array}$ & $\begin{array}{l}\text { General } \\
\text { fertility } \\
\text { rate(2) }\end{array}$ & $\begin{array}{l}\text { Marital } \\
\text { fertility } \\
\text { rate }\end{array}$ & $\begin{array}{l}\text { Illegitimate } \\
\text { fertility } \\
\text { rate }\end{array}$ & $\begin{array}{l}\text { Illegitimate } \\
\text { fertility } \\
\text { ratio }\end{array}$ \\
\hline \multirow[t]{4}{*}{ Ware } & Hoddesdon & No & $\mathrm{R}$ & 99 & 100 & 229 & 4.5 & 26 \\
\hline & Stanstead & No & $\mathrm{R}$ & 152 & 153 & 282 & 19.9 & 65 \\
\hline & Ware & No & $U$ & 160 & 161 & 278 & 26.8 & 78 \\
\hline & Standon & No & $\mathrm{R}$ & 159 & 159 & 273 & 16.7 & 47 \\
\hline \multirow[t]{4}{*}{ Bishop's Stortford } & Sawbridgeworth & No & $\mathrm{R}$ & 141 & 142 & 252 & 16.5 & 55 \\
\hline & Stansted & No & $\mathrm{R}$ & 173 & 172 & 296 & 18.3 & 47 \\
\hline & Bishop's Stortf'd & No & $\mathrm{U}$ & 140 & 143 & 282 & 24.4 & 92 \\
\hline & Braughing & No & $\mathrm{R}$ & 164 & 164 & 287 & 23.1 & 65 \\
\hline \multirow[t]{3}{*}{ Royston } & Buntingford & No & $\mathrm{R}$ & 151 & 153 & 271 & 20.0 & 61 \\
\hline & Royston & No & $\mathrm{R}$ & 158 & 159 & 281 & 18.1 & 53 \\
\hline & Melbourn & No & $\mathrm{R}$ & 158 & 160 & 280 & 20.4 & 56 \\
\hline \multirow[t]{2}{*}{ Hitchin } & Baldock & Yes & $\mathrm{R}$ & 131 & 132 & 246 & 16.6 & 62 \\
\hline & Hitchin & Yes & $\mathrm{U}$ & 153 & 153 & 296 & 27.8 & 96 \\
\hline \multirow[t]{2}{*}{ Hertford } & Watton & No & $\mathrm{R}$ & 167 & 167 & 295 & 18.9 & 53 \\
\hline & Hertford & No & $U$ & 112 & 112 & 230 & 13.1 & 63 \\
\hline \multirow[t]{2}{*}{ Hatfield } & Hatfield & Yes & $\mathrm{R}$ & 145 & 144 & 274 & 21.6 & 77 \\
\hline & Welwyn & No & $\mathrm{R}$ & 147 & 147 & 305 & 14.5 & 54 \\
\hline \multirow[t]{2}{*}{ St Albans } & Harpenden & Yes & $\mathrm{R}$ & 142 & 141 & 272 & 21.8 & 80 \\
\hline & St Albans & Yes & $\mathrm{U}$ & 122 & 122 & 254 & 24.3 & 114 \\
\hline \multirow[t]{4}{*}{ Watford } & Bushey & No & $\mathrm{R}$ & 149 & 149 & 311 & 12.2 & 44 \\
\hline & Watford & No & $U$ & 141 & 141 & 278 & 24.2 & 93 \\
\hline & Rickmansworth & No & $\mathrm{R}$ & 151 & 152 & 282 & 25.5 & 85 \\
\hline & Abbots Langley & Yes & $\mathrm{R}$ & 144 & 145 & 283 & 14.6 & 52 \\
\hline \multirow[t]{3}{*}{ Hemel Hempstead } & Kings Langley & Yes & $\mathrm{R}$ & 139 & 140 & 287 & 17.2 & 67 \\
\hline & Hemel Hemp. & Yes & $U$ & 140 & 140 & 274 & 19.7 & 74 \\
\hline & Flamstead & Yes & $\mathrm{R}$ & 164 & 165 & 305 & 26.5 & 81 \\
\hline \multirow[t]{2}{*}{ Berkhamsted } & Berkhamsted & Yes & U & 129 & 130 & 283 & 19.0 & 84 \\
\hline & Tring & Yes & $U$ & 139 & 140 & 268 & 21.1 & 78 \\
\hline \multicolumn{4}{|l|}{ Hertfordshire } & 143 & 144 & 274 & 20.3 & 73 \\
\hline \multicolumn{4}{|l|}{ Straw industry RDs } & 139 & 140 & 274 & 22.2 & 85 \\
\hline \multicolumn{4}{|l|}{ Non-straw RDs } & 146 & 147 & 274 & 18.5 & 63 \\
\hline \multicolumn{4}{|l|}{ Rural straw RDs } & 141 & 142 & 270 & 19.7 & 72 \\
\hline \multicolumn{4}{|l|}{ Rural non-straw RDs } & 152 & 152 & 279 & 17.4 & 55 \\
\hline \multicolumn{4}{|l|}{ Urban RDs } & 137 & 138 & 271 & 22.6 & 88 \\
\hline \multicolumn{4}{|l|}{ Rural RDs } & 148 & 149 & 276 & 18.2 & 60 \\
\hline \multicolumn{9}{|c|}{$\begin{array}{l}\text { Notes: General fertility rate(1) uses data from the published census report. } \\
\text { General fertility rate(2) uses data compiled from the Census Enumerators' Books. } \\
\text { Sources: Digitized } 1851 \text { Census Enumerators' Books; Annual Reports of the Registrar General for } \\
\text { Births, Deaths and Marriages, } 1847-55 \text {. }\end{array}$} \\
\hline
\end{tabular}


offspring. More generally, examination of the conflated figures for straw and nonstraw, and rural and urban, RDs at the foot of Table 2, suggests that differences are exaggerated by ratios compared to illegitimate fertility rates. Part of the explanation lies in different levels of marital fertility, particularly the higher level in the rural nonstraw RDs compared with the rural straw RDs, but more significant still is the relative proportions of women aged 15-44 who were single/widowed or married, which were consistently substantially higher than average in the straw and urban regions of the county, and lower in the non-straw and rural regions. ${ }^{38}$

Turning to the possible relationship between the straw industry and illegitimate fertility, the rate was generally higher-22.2 compared to 18.5 per 1,000 - in the straw industry RDs than in the non-straw, though far less than the illegitimacy ratio would indicate. When the urban influence is allowed for, however, the difference narrows further, the rate standing at 19.7 in rural straw areas and 17.4 in rural non-straw districts. The small towns of mid-nineteenth century Hertfordshire, as a group, exhibited considerably higher illegitimate fertility ratios and rates than did the rural areas, contradicting the conclusions about lower urban illegitimacy drawn by Laslett from the ratios for 1842 and 1845 presented in the Registrar General's $8^{\text {th }}$ Annual Report, and also contrasting with Armstrong's results for Norfolk. ${ }^{39}$ Furthermore, there is no correspondence between legitimate and illegitimate fertility, long regarded as a general feature of the English demographic experience over the long-term, and again evident in nineteenth-century Norfolk. ${ }^{40}$ In mid-nineteenth century Hertfordshire, rural districts exhibited higher general and marital fertility than urban ones, but lower illegitimate fertility. 
These are, of course, generalizations to which there are exceptions. While illegitimacy ratios and, to a lesser degree rates, generally stood slightly higher in the straw districts, they were well below average in Baldock even though 53 per cent of occupied females were employed in the industry here. Similarly in Abbots Langley, where the straw industry accounted for 30 per cent of female employment, illegitimacy stood well below the county average. In the Hemel Hempstead RD both the illegitimacy ratio and rate were modest, notwithstanding the presence of the straw trades and its incorporation of one of the county's leading towns. And while most towns usually exhibit rates close to or significantly above the county average, in Hertford illegitimacy was particularly low. ${ }^{41}$

These differences between straw and non-straw, and urban and rural, areas must also to be kept in perspective. The illegitimacy ratios found in the groups of districts analyzed by the Registrar General for 1845 range from 174 per 1,000 in Brampton, Longtown and Wigan in Lancashire down to just 10 in the City of London or-if London is excluded-30 in Swansea. The county ratios for 1852 range from 114 per 1,000 in Norfolk to 48 in Monmouthshire. ${ }^{42}$ In 1870-2, the English county illegitimacy rates in the 73rd Annual Report range from 29.2 in Cumberland to 9.4 in Middlesex. ${ }^{43}$ Neither illegitimacy ratios nor rates were particularly high in midnineteenth century Hertfordshire, therefore, and nor were the intra-county differences between straw and non-straw and urban and rural areas particularly marked compared with broader regional variations across the country.

In the absence of appropriate data on age, sex and marital structure in the published census reports it is impossible to calculate illegitimacy rates at the level of 
Table 3 : Fertility in Hertfordshire by SRD, 1847-5, 1867-75, 1887-95

\begin{tabular}{|c|c|c|c|c|c|c|c|c|c|c|}
\hline \multirow[b]{2}{*}{ SRD } & \multirow[b]{2}{*}{$\begin{array}{l}\text { Straw } \\
\text { district }\end{array}$} & \multicolumn{3}{|c|}{$\begin{array}{l}\text { General } \\
\text { fertility rate }\end{array}$} & \multicolumn{3}{|c|}{$\begin{array}{l}\text { Marital } \\
\text { fertility rate }\end{array}$} & \multicolumn{3}{|c|}{$\begin{array}{l}\text { Illegitimate } \\
\text { fertility rate }\end{array}$} \\
\hline & & $\begin{array}{l}1847 \\
-55\end{array}$ & $\begin{array}{l}1867 \\
-75\end{array}$ & $\begin{array}{c}1887 \\
-95\end{array}$ & $\begin{array}{l}1847 \\
-55\end{array}$ & $\begin{array}{l}1867 \\
-75\end{array}$ & $\begin{array}{l}1887 \\
-95\end{array}$ & $\begin{array}{l}1847 \\
-55\end{array}$ & $\begin{array}{l}1867 \\
-75\end{array}$ & $\begin{array}{l}1887 \\
-95\end{array}$ \\
\hline Ware & No & 140 & 151 & 129 & 264 & 298 & 27 & 15.9 & 12.3 & 6 \\
\hline Bishop's Stortford & No & 153 & 156 & 128 & 280 & 294 & 266 & 21.4 & 17.9 & 12.7 \\
\hline Royston & No & 158 & 179 & 137 & 278 & 311 & 262 & 19.1 & 20.9 & 15.0 \\
\hline Hitchi & Yes & 146 & 147 & 129 & 278 & 299 & 27 & 24.2 & 21.7 & 14.9 \\
\hline Hertford & No & 127 & 145 & 122 & 250 & 285 & 257 & 14.4 & 15.9 & 10.0 \\
\hline Hatfield & No & 145 & 151 & 130 & 281 & 307 & 275 & 19.6 & 15.9 & 9.2 \\
\hline St Albans & Yes & 129 & 136 & 124 & 261 & 286 & 267 & 23.4 & 19.9 & 11.3 \\
\hline Watfc & No & 147 & 138 & 120 & 287 & 288 & 264 & 20.6 & 13.2 & 7.5 \\
\hline Hemel Hempstead & d Yes & 146 & 139 & 122 & 284 & 287 & 258 & 20.5 & 17.8 & 11.7 \\
\hline Berkhamsted & Yes & 135 & 148 & 124 & 274 & 306 & 262 & 20.1 & 18.9 & 12.4 \\
\hline Hertfordshire & & 144 & 149 & 126 & 274 & 296 & 266 & 20.3 & 17.7 & 11.2 \\
\hline Strav & & 14 & 143 & 12 & 274 & 294 & 26 & 22.5 & 19.9 & 12.7 \\
\hline Non-straw SRDs & & 146 & 154 & 126 & 274 & 297 & 266 & 18.6 & 15.9 & 10.1 \\
\hline England \& Wales* & & 143 & 153 & 130 & 281 & 292 & 264 & 18.1 & 16.7 & 10.5 \\
\hline
\end{tabular}

Notes: all data on age and marital condition is taken from the census reports except that for the general fertility rate and marital condition by age group in 1851, which are taken from conflation of data extracted from digitized Census Enumerators' Books.

The discrepancy between the non-straw SRD figure for the general fertility rate in 1851 given here (146) and that for non-straw RDs in Table 4 (147) is due to the classification of the Hatfield SRD as non-straw, but the Hatfield RD as straw.

* Figures for England \& Wales are calculated as five-year rather than nine-year averages (1849-53 etc).

Sources: Digitized Hertfordshire CEBs 1851; Census reports 1851, 1871, 1891; Annual Reports of the Registrar General of Births, Deaths and Marriages; A. Armstrong, The Population of Victorian and Edwardian Norfolk (Norwich, 2000), Tables 5.1 and 5.3, pp. 107, 117.

the RD across the later nineteenth century. Instead we have to rely upon the less geographically precise SRD which, while it still provides a fairly reliable indication of the straw and non-straw areas of the county, prevents further urban/rural comparison in a county with towns as small as those of Hertfordshire. For analysis by RD, we are forced back upon illegitimacy ratios. In Table 3 changing levels of general, marital 
and illegitimate fertility by SRD are presented, and in Table 4 illegitimacy ratios by $\mathrm{RD}$, the latter calculated from conflated figures from parish registers for 1813-20, from the Registrar Generals' reports from 1842 forwards, supplemented by county and national data extracted from the parish register abstracts for 1830 and $1840 .{ }^{44}$ Table 3 reveals a similar disparity in illegitimacy rates between straw and non-straw SRDs in $1847-55$ as Table 2. That disparity was maintained through to $1867-75$, when the straw industry was at its height, narrowing considerably towards the end of the century by when it was rapidly declining. Illegitimacy rates fell dramatically across this period, as in England as a whole, but while the continued disparity between the straw and non-straw areas suggests a degree of persistence even in the face of rapidly changing economic circumstances, rates of decline varied considerably from district to district, which is reflected in the fact that the correlation coefficient between the two series centred upon 1871 and 1891 , at 0.44 , is positive but weak. By the late 1880 s and early 1890 s rapidly expanding Watford had fallen to the bottom of the Hertfordshire illegitimacy league table, while the only district to experienced absolute population decline across the second half of the nineteenth century, Royston, had moved to the top. While the data for general and marital fertility in Table 3 indicate convergence over time towards the mean, by the later part of the century the disparity between districts with regard to rates of illegitimate fertility were larger than they had been at mid-century, albeit at substantially lower absolute levels.

Table 4 provides data that is geographically more sensitive but methodologically more problematic. Nevertheless, bearing in mind that ratios are likely to exaggerate the differences between straw and non-straw and urban 
Table 4 : Illegitimacy Ratios in Hertfordshire by RD, 1813-20 to 1887-95

\begin{tabular}{|c|c|c|c|c|c|c|c|c|c|c|}
\hline \multicolumn{2}{|l|}{ SRD } & $\begin{array}{l}\text { Straw } \\
\text { District }\end{array}$ & $\begin{array}{c}\text { Urban/ } \\
\text { Rural }\end{array}$ & $\begin{array}{c}1813- \\
20\end{array}$ & 1830 & 1840 & $1842 / 5$ & $\begin{array}{c}1847- \\
55\end{array}$ & $\begin{array}{c}1867 \\
-75\end{array}$ & $\begin{array}{c}1887- \\
95\end{array}$ \\
\hline \multirow[t]{4}{*}{ Ware } & Hoddesdon & No & $\mathrm{R}$ & 32 & & & & 26 & 36 & 35 \\
\hline & Stanstead & No & $\mathrm{R}$ & 37 & & & & 65 & 43 & 20 \\
\hline & Ware & No & $U$ & 35 & & & & 78 & 46 & 46 \\
\hline & Standon & No & $\mathrm{R}$ & 53 & & & & 47 & 44 & 47 \\
\hline \multirow[t]{4}{*}{ Bishop's Stortford } & Sawbridgeworth & No & $\mathrm{R}$ & 40 & & & & 55 & 53 & 49 \\
\hline & Stansted & No & $\mathrm{R}$ & $\mathrm{n} / \mathrm{a}$ & & & & 47 & 40 & 34 \\
\hline & Bishop's Stortf'd & No & $U$ & 36 & & & & 92 & 71 & 70 \\
\hline & Braughing & No & $\mathrm{R}$ & 39 & & & & 65 & 53 & 46 \\
\hline \multirow[t]{3}{*}{ Royston } & Buntingford & No & $\mathrm{R}$ & 31 & & & & 61 & 60 & 63 \\
\hline & Royston & No & $\mathrm{R}$ & 36 & & & & 53 & 48 & 56 \\
\hline & Melbourne & No & $\mathrm{R}$ & $n / a$ & & & & 56 & 53 & 50 \\
\hline \multirow[t]{2}{*}{ Hitchin } & Baldock & Yes & $\mathrm{R}$ & 24 & & & & 62 & 63 & 56 \\
\hline & Hitchin & Yes & $U$ & 31 & & & & 96 & 89 & 70 \\
\hline \multirow{2}{*}{ Hertford } & Watton & No & $\mathrm{R}$ & 35 & & & & 53 & 54 & 47 \\
\hline & Hertford & No & $U$ & 27 & & & & 63 & 59 & 44 \\
\hline \multirow[t]{2}{*}{ Hatfield } & Hatfield & Yes & $\mathrm{R}$ & 22 & & & & 77 & 57 & 40 \\
\hline & Welwyn & No & $\mathrm{R}$ & 34 & & & & 54 & 52 & 34 \\
\hline \multirow[t]{2}{*}{ St Albans } & Harpenden & Yes & $\mathrm{R}$ & 25 & & & & 81 & 78 & 50 \\
\hline & St. Albans & Yes & $U$ & 35 & & & & 114 & 84 & 51 \\
\hline \multirow[t]{4}{*}{ Watford } & Bushey & No & $\mathrm{R}$ & 33 & & & & 44 & 38 & 26 \\
\hline & Watford & No & $U$ & 55 & & & & 93 & 64 & 46 \\
\hline & Rickmansworth & No & $\mathrm{R}$ & 28 & & & & 85 & 52 & 24 \\
\hline & Abbots Langley & Yes & $\mathrm{R}$ & 29 & & & & 52 & 41 & 29 \\
\hline \multirow[t]{3}{*}{ Hemel Hempstead } & Kings Langley & Yes & $\mathrm{R}$ & 27 & & & & 67 & 57 & 37 \\
\hline & Hemel Hemp. & Yes & $U$ & 29 & & & & 74 & 72 & 50 \\
\hline & Flamstead & Yes & $\mathrm{R}$ & 35 & & & & 81 & 77 & 76 \\
\hline \multirow[t]{2}{*}{ Berkhamsted } & Berkhamsted & Yes & $U$ & 41 & & & & 84 & 70 & 52 \\
\hline & Tring & Yes & $U$ & 32 & & & & 78 & 71 & 58 \\
\hline \multicolumn{2}{|l|}{ Hertfordshire } & & & 33 & 36 & $50 / 52$ & $70 / 74$ & 73 & 63 & 49 \\
\hline \multicolumn{2}{|l|}{ England \& Wales } & & & $\mathrm{n} / \mathrm{a}$ & 52 & 61 & $67 / 70$ & 66 & 55 & 44 \\
\hline \multicolumn{2}{|l|}{ Straw industry RDs } & & & 30 & & & & 85 & 74 & 54 \\
\hline \multicolumn{2}{|l|}{ Non-Straw RDs } & & & 35 & & & & 63 & 53 & 44 \\
\hline \multicolumn{2}{|l|}{ Rural straw RDs } & & & 26 & & & & 71 & 65 & 49 \\
\hline \multicolumn{2}{|l|}{ Rural non-straw RDs } & & & 35 & & & & 55 & 49 & 41 \\
\hline \multicolumn{2}{|l|}{ Urban RDs } & & & 34 & & & & 88 & 73 & 54 \\
\hline \multicolumn{2}{|l|}{ Rural RDs } & & & 31 & & & & 60 & 54 & 43 \\
\hline
\end{tabular}

Notes: The data for a number of RDs in 1813-20 is incomplete, as the parish register evidence has been collected for the ancient county rather than the registration county. The omissions are only significant in Sawbridgeworth and Royston, but there is no reason to believe that the data presented here will be 
Unrepresentative. The 1830 figure is for the ancient county; the two figures for 1840 are, respectively, for the ancient and the registration county. SRDs were grouped in 1842/5: the figures for Hatfield, Hertford, Ware and Bishop's Stortford collectively were 64 and 66; Royston and Hitchin 69 and 65; St Albans, Watford, Hemel Hempstead and Berkhamsted 76 and 90.

Sources: 1813-20 parish registers; 1830/1840 Parish Register Abstracts - British Parliamentary Papers 1833, xxviii, 1845, xxv; 1847-55 to 1887-95 Annual Reports of the Registrar General for Births, Deaths and Marriages.

and rural areas, they tell much the same story as the illegitimacy rates in Table 3 . The disparity between straw and non-straw RDs evident in 1847-55 was maintained through to $1867-75$ as the industry rose to its height, and narrowed substantially without disappearing completely as it declined from the 1870s. Urban/rural differences were much wider to begin with for the reasons discussed above, providing part of the explanation for the differences between straw and non-straw areas in 184755 and 1867-75, but had narrowed considerably by 1887-95. Rates of decline again varied from district to district, a feature reflected in a positive but weak correlation coefficient of 0.42 . The illegitimacy ratio in the St Albans district fell by more than half, despite the fact that here the straw hat trade continue to offer considerable employment opportunities for women long after straw plaiting had succumbed to foreign competition, while in Baldock, largely a plaiting rather than a straw hat area, the illegitimacy ratio declined only marginally. The district to suffer most dramatically from the decline of plaiting by 1891 was Harpenden, for here in 1851 fully 37 per cent of the total female population worked in the straw industry, a figure which had slumped to under 10 per cent forty years later, but the rate of decline in the illegitimacy ratio was only marginally above that for the straw areas collectively, and only 5 per cent higher than the decline experienced in the county as a whole. ${ }^{45}$ In each 
of the three RDs in the Royston region illegitimacy ratios were largely maintained at their mid-century level.

Illegitimacy rates were, therefore, generally marginally higher in straw than in non-straw districts of Hertfordshire in the later nineteenth century, and this disparity was exaggerated with respect to illegitimacy ratios through the ability of these areas to attract large number of young, unmarried females. As the industry declined, the straw and non-straw regions converged towards the national average. But a substantial part of the divergence can be explained by the situation of Hertfordshire towns within the key straw areas, while there are exceptions to the general correspondence between straw areas and high rates and ratios, and no clear correlation between the rate of the industry's decline by district and falling illegitimacy. Rapidly declining illegitimacy in the Watford region, and its obstinate refusal to fall in Royston, serve to underline the fact that there were many other influences impacting upon illegitimacy rates in the later nineteenth century apart from straw plait.

Before leaving the issue of illegitimacy, the very low ratios identified for 1813-20 deserve comment, standing as they do well below the national average calculated from seventy-four parishes by Laslett. ${ }^{46}$ If these figures are accurate, and a degree of scepticism must arise from the fact that thirteen of the 132 Hertfordshire parishes produce nil returns, the rise in illegitimacy between the 1820 s and early 1850s was far more dramatic than previous estimates have suggested. Indeed, as the ratio for Hertfordshire had already reached 70 per 1,000 by 1842 , at face value these figures suggest illegitimacy more than doubled in little over twenty years. ${ }^{47}$ Even if parish registers were significantly under-recording illegitimate births by this date, the 
parish register data in Table 4 considered on its own still suggests a substantial increase. Interestingly, those areas of Hertfordshire which by mid-century were prominent straw regions, and exhibited relatively high illegitimacy ratios, collectively exhibit relatively low figures in the $1810 \mathrm{~s} .{ }^{48}$ Urban districts, on the other hand, already reveal slightly higher ratios than rural ones. Although no occupational data is available for the early nineteenth century, the straw industry was doubtless far less developed in the 1810 s than it was by the 1840 s, and those regions where the industry became established grew particularly rapidly during the first half of the century, and developed sex ratios skewed towards women as a result of sex-selective net migration. ${ }^{49}$ If rising illegitimacy ratios were by no means confined to these parts of the county, it is plausible to suggest that the fuller establishment of the straw industry had a more pronounced impact, partly in impacting directly-if relatively marginally — upon levels of illegitimacy, but also by causing the skewed age and marital structure that produced the exaggerated illegitimacy ratios in these areas shown in Tables 2 and $4 .^{50}$

\section{$\mathbf{V}$}

Regarding the influence of the industry upon young people's patterns of residence and the precocious independence of straw plait workers, contemporaries offered conflicting views. In 1843 John Hodgson, surgeon, complained of the 'early casting off of the control of their parents', due to the ability of straw plaiters to support themselves at a young age. ${ }^{51}$ Similarly in 1862 , it was suggested that 'As they grow up they do not care so much about their parents, and leave them' ${ }^{52}$ The 1867 Report 
of the Royal Commission on the Employment of Children, Young Persons and Women in Agriculture blamed the lack of chastity among straw plait girls on 'the early age at which, when plait is good, they become independent of their parents, and often leave their homes... .53 But while Mr Austin of Luton suggested that 'girls soon become independent of their parents, and go and lodge in Luton or elsewhere', the Reverend Blomfield of Barton in the Clay was less categorical, suggesting on the one hand that 'girls who plait sometimes separate themselves from their own families and lodge with other families', but also that 'The females in these parts are employed in straw plait, the effect of which is to keep at home all the females'. ${ }^{54}$ The agricultural writer Henry Evershed shared the latter opinion, arguing that the straw plait industry kept families intact by allowing children to make a contribution to the family budget and providing an alternative to both agricultural labour and domestic service, and hence 'retains them at home'. 55

Analysis of the Berkhamsted and St Albans SRDs (population 29,569), the very heart of the county's straw plait region, allows these views to be tested. The Berkhamsted district comprised the parishes of Aldbury, the hamlet of Frithsden, the town of Great Berkhamsted, and the parishes of Tring (incorporating the town), Little Gaddesden, Northchurch, Puttenham and Wigginton. The parish of Wigginton gives little support to the notion of early independence. Here eleven of the thirty-one males aged 10-14 were plaiters, all described as the son of the head of household, living at home. Of the thirty-three female plaiters in the same age group, twenty-eight were daughters, three granddaughters, and two were visitors. Among those aged 15-19 there was only one male plaiter, but thirty-seven females, of whom thirty-two were 
daughters (including one step-daughter), one a granddaughter, one a niece and just three were apparently unrelated to the head of household (two lodgers and one visitor). In Frithsden there were twenty female straw plaiters aged between 10 and 14, and twenty-six aged 15-19, all of whom were related to the head of household. In Aldbury just two of the thirty-seven plaiters aged 10-14 were apparently unrelated to the head of household (one lodger and one visitor), and just one of the twenty-three aged 15-19 (described as a visitor).

The parish of Tring provides marginally more evidence of early independence. In the age group 10-14, seven of 144 female straw plaiters were lodgers, as were thirteen of the 130 aged 15-19. The latter figure can be compared, however, to the forty-one domestic servants in the parish in this age group living away from home. In Great Berkhamsted there were thirty-three straw workers aged 10-14 and only one lodger amongst them, and sixty aged 15-19 of whom two were lodgers and four were visitors, while forty-seven teenage girls were in service. In adjacent Northcurch there was not a single lodger amongst the sixty-six straw workers aged 10-19 and just two visitors (aged 16 and 18). None of the twenty-five plaiters aged 10-19 in Little Gaddesden were lodgers or visitors, while all fifteen plaiters in this age group in the parish of Puttenham were daughters of the head of household.

The St Albans SRD, incorporating the town of St Albans, its out-hamlets, and the surrounding villages of Harpenden, Redbourn, Sandridge and Wheathampsteada total population of 17,991 - provides even more compelling evidence to refute the suggestion that the straw trade induced children to desert their parents at an early age. A count of all female straw workers aged 10-14 in the rural parts of the district both 
within and without the Liberty of St Albans produces a total of 224, of which a mere two ( 0.9 per cent) were lodgers. Of the 224,200 were the daughter or step-daughter of the head of household, seven were grandchildren, six were nieces, three sisters and one a cousin, the balance made up by four who were visiting on census night. In the age group 15-19 there were 273 straw workers, just nine (3.3 per cent) of whom were lodgers, while 223 are described as daughter or step-daughter of the household head, the remainder comprising of more distant relatives. In a population of 10,763 , therefore, there were just eleven teenage straw plaiters lodging in households to which they were apparently unrelated. Amongst the same sample there were thirty-five teenage male straw plaiters, thirty-four of whom were sons and the other a nephew of the head of household. Far from providing an incentive for young men and women to leave home early, therefore, the straw industry in the rural parts of the St Albans SRD appears to have encouraged families to remain intact.

The borough of St Albans offers a little more evidence of early independence. Here 1,351 individuals worked in the straw, straw hat, Brazilian hat and related textile trades. Girls aged 10-14 accounted for 163 of these, of whom just three (1.8 per cent) were lodgers living without their parents. ${ }^{56}$ One hundred and thirty-nine were daughters or step-daughters, and apart from one visitor the rest were kin. Of the 196 aged 15-19 there were twelve lodgers, still only 6 per cent of the total. However, as many as six in this age group headed their own households, four working in the hat trades and two in silk, giving a glimpse of the occasional opportunities for female independence these trades provided. Boys in the town were as unadventurous as their rural counterparts, 104 of the 107 aged 10-14 being the son of the head of household, 
the other three more distant relatives. At age 15-19 there were four unrelated male lodgers out of seventy-six ( 5 per cent), while another four headed their own households. If more teenage boys and girls working in the straw and hat trades had left home in town than in countryside, therefore, this was a difference of degree rather than of kind, and overall in this district those who had ventured abroad were a small minority of the total, dwarfed by the number who left home to enter domestic service or service in husbandry. The situation in both rural and urban Hertfordshire is therefore similar to that in mid-nineteenth century Preston, where few children actually left home to live in lodgings despite widespread contemporary testimony that they did so. ${ }^{57}$ There is also clear evidence that in the straw plait and hat areas of the county there was a greater willingness to accommodate resident kin than in those parts where the industry was absent, particularly sisters (in-law), nieces and granddaughters, their value as additional sources of income providing an economic incentive to cement family relationships beyond the immediate nuclear family. ${ }^{58}$

\section{VI}

How saucy did it make the poor? In the sense that Arthur Young intended- the straw plait and hat industry providing alternative employment which made recruitment of servants more difficult - there is some evidence. Full occupational information is available for twenty-three of the twenty-eight RDs in the registration county for 1851 , eleven of which provided substantial employment opportunities in the straw industry. In these eleven collectively there were 36 female domestic servants per 1,000 of the population, while in the twelve non-straw districts the figure stood at 50 per 1,000. 
Furthermore, five of the six districts with the lowest proportion of domestic servants were straw districts, while all of the six districts with the highest proportion of servants were not. While Young exaggerated by claiming that no servants could be procured in these areas, therefore, the straw industry did provide alternative opportunities that substantial numbers of women took advantage of.

In the wider sense of the impact of the straw plait and hat trades on illegitimacy and the family, it is clear that those contemporaries who emphasized its baneful and overriding influence were wide of the mark, reflecting the social distance that existed between the middle-class commentators that gave evidence to Royal Commissions of enquiry, an unquestioned assumption that illegitimacy was an issue of morality, and a willingness to find individuals culpable rather than to couch explanations in terms of broader economic and social influences. In the midnineteenth century illegitimacy in Hertfordshire, either in general or in the straw plait and hat making areas in particular, was not notably high by contemporary standards, standing only marginally above the national average and on a par with the great majority of counties in southern England and the Midlands. Although in areas where the straw plait and hat trades established themselves illegitimacy rates stood generally slightly higher than in those parts of the county where it was absent, the difference was relatively small and the relationship was far from consistent, both when the trade was flourishing and after it had gone into decline. The fact that Hertfordshire was one of the very few counties to change its illegitimacy rank order substantially between 1870 and 1900, remarked upon by Laslett, cannot be attributed wholly or even mainly to the decline of straw plaiting, for the decline of illegitimacy was a general feature of 
straw and non-straw areas alike between 1851 and $1891{ }^{59}$ Furthermore, the high illegitimacy ratios found in some straw industry districts are partly an optical illusion, resulting from the existence of a larger 'at risk' population produced by the skewed age, sex and marital structure that the industry encouraged. Similar demographic profiles in Hertfordshire towns also contributed towards this impression, although illegitimacy rates were also higher in most urban centres, while in rural areas the rates found in straw districts were only slightly higher than those found in non-straw districts. ${ }^{60}$ Very little evidence of early female independence emerges from the rural areas of Hertfordshire, whether or not they were heavily engaged in the straw industry. Indeed, it appears that the industry encouraged family cohesion, both among and beyond immediate kin.

In terms of illegitimacy rates and, to a degree, in terms of opportunities for early female independence, urban/rural differences stand out more prominently in the data assembled here. Most towns exhibited skewed sex ratios, particularly among teenagers and young adults, and it is possible that this led to competition for male marriage partners and greater willingness to engage in pre-marital sexual liaisons. One result of this skew was that female age at marriage was generally higher in towns, a feature which is indicated both by calculation of the singulate mean age at marriage and proportions married in the age group $20-24 .{ }^{61}$ In rural straw districts sex ratios were also often similarly skewed, but here a higher proportion of women married earlier despite this. As a test of Laslett's 'courtship intensity' model of illegitimacy, therefore, Hertfordshire towns and rural straw districts offer contradictory evidence. $^{62}$ 
A further possible reason for higher urban illegitimacy is that urban populations were to some degree self-selecting, in that the very act of migrating to a town reflected a spirit of adventure and independence which might also have had implications for sexuality, while the more conservative young women kept themselves safe at home. It is also possible that unmarried, pregnant women may have headed for towns to take advantage of the relative anonymity that they might find there, but this is difficult to substantiate or quantify.

Towns, of course, often included large numbers of female domestic servants, although the discrepancy between town and countryside in this respect can be overstated. When the twenty-three Hertfordshire RDs for which full occupational information is available are classified as urban or rural on the same basis as in Table 2 , the number of domestic servants per 1,000 of the population is virtually identical in each group. While this might be partially a product of the fact that RDs are larger areas that incorporate rather than constitute towns, analysis of the St Albans SRD reveals that in the town 23 per cent of occupied females worked in domestic service and service trades, while in the rural parishes the figure stood close behind at 18 per cent. Neither is the relationship between service and illegitimacy clear cut. Although for later nineteenth-century England Schellekens found a positive correlation between illegitimacy and the proportion of the female population in service, urban studies have tended to reveal low rather than high levels, notably in London. ${ }^{63}$ The Hertfordshire evidence shows an inverse relationship between levels of domestic service in the respective RDs and illegitimacy rates in 1851, the correlation coefficient standing at 
-0.64. Furthermore, levels of domestic service help to explain some of the apparent puzzles or anomalies in Table 2. The Hoddesdon district, for instance, with its extremely low illegitimacy rate of 4.5 per 1,000 , possessed the highest level of female domestic service in the county, at 76 per 1,000 of the population compared with a county average of just 42. High levels of service were also found in Welwyn, Hertford and Bushey, each of which also exhibited relatively low illegitimacy rates, the town of Hertford subverting the more usual urban tendency to higher illegitimacy. Although domestic servants lacked parental control, the authority exerted by masters and mistresses, the potential loss of references and hence employment consequent upon 'misbehaviour' and the long hours of work may all have imposed a more powerful restraining influence, counteracting the greater opportunities for social mixing towns provided. ${ }^{64}$ If this is the case, the concerns reported by Arthur Young may, therefore, have indirectly encouraged higher illegitimacy, the attraction of employment in the straw plait and hat trades luring more young women away from the protective confines that domestic service provided.

The rise and fall of illegitimacy across the nineteenth century presents a continuing conundrum, even if it is now clear that explanations couched in terms of the supposed promiscuity of particular occupational groups are unlikely to prove helpful. Further attention needs to be paid to the substantial rise in illegitimacy ratios that occurred in some areas between circa 1820 and 1842/5, shown for Hertfordshire in Table 4. The rise was equally dramatic in some other counties, and substantial in still more, as the data in Table 5 indicates, and took place during a period when nuptiality and marital fertility were falling. ${ }^{65}$ While part of the explanation for 
Table 5 : Illegitimacy Ratios in English Counties 1813-20 - 1842/5

\begin{tabular}{|c|c|c|c|c|c|c|c|}
\hline & $1813-20$ & 1830 & 1840 & 1842 & 1845 & \multicolumn{2}{|c|}{ average $1813-20 / 1842 / 5$} \\
\hline Buckinghamshire & 30 & 46 & 72 & 73 & 72 & 73 & 141 \\
\hline Bedfordshire & 34 & 34 & 75 & 77 & 83 & 80 & 136 \\
\hline \multirow{2}{*}{$\begin{array}{l}\text { Hertfordshire } \\
\text { Cambridgeshire }\end{array}$} & 32 & 36 & 50 & 70 & 74 & 72 & 122 \\
\hline & 42 & 40 & 65 & 72 & 70 & 71 & 67 \\
\hline Northamptonshire & 42 & 42 & 50 & 64 & 63 & 64 & 50 \\
\hline \multirow{2}{*}{$\begin{array}{l}\text { Huntingdonshire } \\
\text { Lancashire }\end{array}$} & 35 & 47 & 54 & 51 & 57 & 54 & 55 \\
\hline & 65 & 78 & 79 & 87 & 82 & 85 & 30 \\
\hline \multirow{2}{*}{$\begin{array}{l}\text { Yorks, North Riding } \\
\text { Yorks, East Riding }\end{array}$} & 70 & 77 & 83 & 89 & 90 & 90 & 28 \\
\hline & 75 & 61 & 67 & 69 & 74 & 72 & -5 \\
\hline \multicolumn{8}{|c|}{$\begin{array}{l}\text { Source: Original parish registers, by courtesy of CAMPOP; BPP 1833, xxxviii, Parish Register } \\
\text { Abstract; BPP 1845, xxv, Parish Register Abstract; 8th Annual Report of the Registrar General for } \\
\text { Births, Deaths and Marriages (London, 1849), p. 73. }\end{array}$} \\
\hline
\end{tabular}

Hertfordshire, Bedfordshire and Buckinghamshire may be the changing age, sex and marital structure consequent upon the development of the straw industry, a more potent explanation - in Hertfordshire and in other arable agricultural counties - may lie in the decline of farm service and consequent increasing vulnerability of the labouring population to the vagaries of an agricultural regime that was struggling to readjust to wartime over-expansion, an over-stocked labour market and increased seasonal unemployment. ${ }^{66}$ In this climate of insecurity, punctuated by the instability that the weather could still produce (in 1841, 1845 and 1846, for example) the chain that joined a promise of marriage, to pre-marital sexual intercourse, to marriage could easily be broken. ${ }^{67}$ On top of this the 1834 Poor Law Amendment Act removed a further cushion by withdrawing out-relief from able-bodied men, offering them the grim prospect of the workhouse in times of unemployment, while simultaneously the bastardy clauses of the same legislation made it much more difficult and expensive for 
mothers to claim paternity, removing jurisdiction from Petty to Quarter Sessions, and requiring corroborative evidence to be produced. ${ }^{68}$ Despite attempts by the Poor Law Commissioners to claim the bastardy clauses of the Act as a success, the parish register abstracts from 1830 and 1840 suggest a steep increase across the decade, while the number of affiliation orders declined in most parts of the country. ${ }^{69}$ The rapid rise in illegitimacy ratios in Hertfordshire and other southern corn-growing counties in the second quarter of the nineteenth century, therefore, may have been the product of continued population growth in the face of a harsh agricultural environment, exacerbated by repressive social legislation. It is unlikely to be coincidental that the years immediately after 1834 also saw a sharp rise in the number of cases of poaching, larceny and assault which came before the bench at the Hertfordshire Quarter Sessions. ${ }^{70}$ In some counties, Hertfordshire included, it is plausible to suggest that illegitimacy ratios were enhanced by the growth of the straw plait industry and hat trades, partly through its direct effect upon willingness to entertain pre-marital sex, partly through its indirect effect in offering alternative employment to the more restrictive domestic service, but also through its impact on sex and marital structures that produced a larger 'at risk' female population. The evidence does not, however, suggest that it was the main cause.

The decline of illegitimacy in the second half of the century also requires more detailed investigation. ${ }^{71}$ The evidence presented here does not suggest the decline of the straw plait and hat trades was the major factor at work in Hertfordshire, and nor could such a local phenomenon explain such a widespread trend, across Hertfordshire or more generally. Adjustment to the provisions of the 1834 Act on the part of men, 
changes to the bastardy clauses of the New Poor Law in 1844 and-more importantly — the reinstatement of the powers of Guardians to initiate paternity proceedings in 1872 , may have diminished the propensity of men to renege on their promises. The extension of the drive against out-relief to women after 1869 may also have had made an impact. ${ }^{72}$ But equally significant may have been the greater economic stability, and (for some at least) the rising living standards associated with high farming and the mid-Victorian boom, within which climate the hitherto largely middle-class values with regard to illegitimacy and marriage may have been increasingly internalized by a working population keen to assert its respectability, producing a change in social mores that made motherhood outside of marriage increasingly unattractive to women from mid-century. ${ }^{73}$ A model couched in terms of growing prosperity allied to the growing demands of parenthood and consequent changes in cultural attitudes was promoted long ago by Tilly, Scott and Cohen, and could well be enhanced by the addition of a regional perspective. ${ }^{74}$ Within Hertfordshire, illegitimacy declined only slowly before the 1870 s, but more rapidly thereafter at the same time as agricultural labour finally reaped more substantial benefits from rising real wages. And while illegitimacy fell everywhere, it fell fastest and furthest in the rapidly expanding region centred upon Watford, and most slowly in the Royston district in the north-east of the county, which was experiencing economic and demographic contraction. But while these are matters requiring further research at the local and regional level, what is now quite clear is that - despite the opinions of many contemporaries - the straw plait and hat trades were a makeweight rather than the mainspring of change. 


\section{NOTES}

${ }^{1}$ A. Young, General View of the Agriculture of the County of Hertfordshire (repr. Newton Abbot, 1971, $1^{\text {st }}$ publ. 1804) [hereafter Young, General View], p. 222. For Young 'saucy' meant unduly independent, the straw plait trade in his view making it difficult to recruit domestic servants and field hands. This paper has a wider remit, and also considers its impact upon levels of illegitimacy.

${ }^{2}$ N. Goose, Population, Economy and Family Structure in Hertfordshire in 1851. Vol. 1 The Berkhamsted Region (Hatfield, 1996), pp. 30-1, 34-46 [hereafter Goose, Berkhamsted]; N. Goose, Population, Economy and Family Structure in Hertfordshire in 1851. Vol. 2 St Albans and its Region (Hatfield, 2000) [hereafter Goose, St Albans], pp. 40-1, 70-5, 82-106; N. Goose, 'The Straw Plait and Hat Trades', in An Atlas of Hertfordshire History, ed. D. Short (Hatfield, 2006); N. Goose, 'The Straw Plait and Hat Trades in Nineteenth-Century Hertfordshire' [hereafter 'Straw Plait'], in N. Goose (ed.), Women's Work in Industrial Britain: Regional and Local Perspectives (Hatfield, 2006); S. Bunker, Strawopolis: Luton Transformed 1840-1876, Bedfordshire Historical Record Society, lxxviii (Bedford, 1999). There is no major, modern history of the industry. See, however, T.G. Austin, The Straw Plaitting, Straw Hat and Bonnet Trade (Luton, 1871); J, Dony, A History of the Straw Hat Industry (Luton, 1942) [hereafter Dony, Straw Hat Industry]; C. Freeman, Luton and the Hat Industry (Luton, 1953); C.M. Law, 'The Straw-Plait and Straw-Hat Industries of the South Midlands', East Midland Geographer, Vol. 4 (1968), 329-41; P. Horn, 'The Buckinghamshire Straw Plait Trade in Victorian England', Records of Buckinghamshire, xix, [hereafter Horn, 'Buckinghamshire'], 42-54; P. Horn, 'Child Workers in the Pillow Lace and Straw Plait Trades of Victorian Buckinghamshire and Bedfordshire', The Historical Journal, xvii (1974), 779-96; N. Agar, Hitchin’s Straw Plait Industry (Hitchin Historical Society, 1978); J. Davis, Straw Plait (Princes Risborough, 1981); C.A. and P. Horn, 'The Social Structure of an "Industrial” Community: Ivinghoe in Buckinghamshire in 1871', Local Population Studies, xxxi (1983), 9-20; L.L. Gróf, Children of Straw. The Story of a Vanished Craft and Industry in Bucks, Herts, Beds and Essex (Buckingham, 1988) [hereafter Gróf, Children of Straw]; P. Sharpe, ‘The Women's Harvest: Straw-Plaiting and the Representation of Labouring Women's Employment, c. 1793-1885', Rural History, v (1994), 129-42 [hereafter Sharpe, 'Women's harvest']; 
N. Verdon, Rural Women Workers in $19^{\text {th }}$-Century England: Gender, Work and Wages (Woodbridge, 2002), pp. 132-63 [hereafter Verdon, Rural Women Workers].

${ }^{3}$ The Victoria County History of Hertfordshire, ed. W. Page (4 Vols., 1904-14), iv, p. 255. See also Goose, St Albans, pp. 71-2.

${ }^{4}$ This and the ensuing analysis draws upon a digitized transcript of the 1851 census enumerators' books for the ancient county, held by the Centre for Regional and Local History at the University of Hertfordshire.

${ }^{5}$ Superintendent Registrar's Districts are often referred to in the demographic literature as Registration Districts, of which there were approximately 600 in England and Wales at mid-century. The ancient county of Hertfordshire was not coterminous with the registration county. Barnet and Edmonton SRDs formed part of Middlesex, but substantial parts fell within the ancient county. While the major portions of the Royston and Bishop's Stortford SRDs fell within Hertfordshire, parts were also situated, respectively, in Cambridgeshire and Essex. There are other, more minor, discrepancies between the two administrative units.

${ }^{6}$ Goose, Berkhamsted, pp. 40-3; Goose, St Albans, pp. 97-100.

${ }^{7}$ E. Grey, Cottage Life in a Hertfordshire Village (St Albans, 1933) [hereafter Grey, Cottage Life], pp. $57,68,70$

${ }^{8}$ Young, General View, p. 223.

${ }^{9}$ W. Cobbett, Cottage Economy (repr. Oxford 1797, $1^{\text {st }}$ publ. 1822), pp. 153, 180-1. Grey also notes how well it fitted into the domestic economy: Cottage Life, pp. 68-70.

${ }^{10}$ A.J. Tansley, 'On the Straw Plait Trade', Journal of the Society of Arts, ix (1860) [hereafter Tansley, 'Straw Plait Trade'], 71-3; Grey, Cottage Life, p. 67.

${ }^{11}$ Tansley, 'Straw Plait Trade', 71; Grey, Cottage Life, p. 119; Report of the Royal Commission on the Poor Laws, British Parliamentary Papers [hereafter BPP] 1834, xxx, pp. 222, 224, 225, 227; Children's Employment Commission: Second Report of the Commissioners on Children's Employment, BPP 1864, xxii, pp. 204, 207.

${ }^{12}$ Children's Employment Commission: Second Report (Trades and Manufactures), BPP 1843, xiv, p. A13. 
${ }^{13}$ W. Cobbett, Rural Rides (2 Vols., Everyman edition, 1912, $1^{\text {st }}$ publ. 1830), i, p. 88. Some previous commentators have suggested that the industry was distinctly seasonal, but the evidence for this is slim and ignores considerable contrary testimony: Sharpe, 'Women's harvest', 136; Verdon, Rural Women Workers, pp. 144-5. For a fuller discussion see Goose, Berkhamsted, pp. 43-4; Goose, St Albans, pp. 102-5; Goose, 'Straw Plait'; ' Goose, 'Cottage Industry, Migration and Marriage in Nineteenth-Century England', (forthcoming) [hereafter Goose, 'Cottage Industry']. The crucial point for the purpose of the following analysis is that there is nothing to indicate that the dates at which the censuses were taken (30 March in 1851, 2 April in 1871 and 5 April in 1891) were in any way untypical. Indeed, even those commentators who argue for seasonality agree that spring and early summer were good periods for plaiting.

${ }^{14}$ Horn, 'Buckinghamshire', 50.

${ }^{15}$ Children's Employment Commission: Second Report (Trades and Manufactures), BPP 1843, xiv, Appendix to $2^{\text {nd }}$ report, paragraphs $88-89$, p. A10.

${ }^{16}$ Ibid., para 90, p. A11.

${ }^{17}$ Children's Employment Commission: Second Report of the Children's Employment Commission, BPP 1864, xxii, p. xl.

${ }^{18}$ Ibid., pp. 202-3.

${ }^{19}$ Report of the Royal Commission on the Employment of Children, Young Persons and Women in Agriculture (1867), BPP 1867-68, xvii, Appendix, Part I, p. 135.

${ }^{20}$ Ibid., Appendix, Part II, pp. 498-9.

${ }^{21}$ Dony, Straw Hat Industry, p. 71.

${ }^{22}$ Grof, Children of Straw, p. 87.

${ }^{23}$ Recent work on England has tended to focus upon the early part of the century: Illegitimacy in Britain, 1700-1920, ed. A. Levene, T. Nutt and S. Williams (Basingstoke, 2005) [hereafter Illegitimacy]. See, however, J. Robin, 'Illegitimacy in Colyton, 1851-1881', Continuity and Change, ii (1987) [hereafter Robin, 'Colyton'], 307-42; B. Reay, Microhistories: Demography, Society and Culture in Rural England, 1800-1930 (Cambridge, 1996) [hereafter Reay, Microhistories], pp. 179212. 
${ }^{24}$ P. Laslett, 'Introduction: Comparing Illegitimacy Over Time and Between Cultures', in Bastardy and its Comparative History, ed. P. Laslett, K, Oosterveen and R.M. Smith (1980) [hereafter Laslett, 'Introduction'], pp. 12-19.

${ }^{25}$ Illegitimacy, passim. Compare A. Wilson, 'Illegitimacy and its Implications in Mid-Eighteenth Century London: the Evidence of the Foundling Hospital', Continuity and Change, iv (1989), 103-64;

T. Hitchcock, 'Re-defining Sex in Eighteenth-Century England', History Workshop Journal, xli (1996), 73-90; R. Trumbach, Sex and the Gender Revolution: Heterosexuality and the Third Gender in Enlightenment London (1998). For a judicious assessment of these arguments, R.B. Shoemaker, Gender in English Society 1650-1850 (1998), pp. 59-86.

${ }^{26}$ For the best recent summaries of the debate, R. Woods, The Demography of Victorian England and Wales (Cambridge, 2000) [hereafter Woods, Demography], pp. 110-69; R. Woods, The Population of Britain in the Nineteenth Century (Cambridge, 1995, $1^{\text {st }}$ published Basingstoke, 1992) [hereafter Woods, Population], pp. 32-40; A. Hinde, England's Population : a History Since the Domesday Survey (2003), pp. 219-43. For a recent analysis which emphasizes the importance of geographical communities, E. Garrett, A. Reid, K. Schürer and S. Szreter, Changing Family Size in England and Wales: Place, Class and Demography, 1891-1911 (Cambridge, 2001), pp. 210-336, 376-400. For local variability see, Reay, Microhistories, pp. 64-7.

${ }^{27}$ R. Adair, Courtship, Illegitimacy and Marriage in Early Modern England (Manchester, 1996) [hereafter Adair, Courtship].

${ }^{28}$ Laslett, 'Introduction', pp. 29-37; Woods, Demography, pp. 142-3 and Fig. 4.12, insert following p. 96, p. c. For Norfolk see A. Armstrong, The Population of Victorian and Edwardian Norfolk (Norwich, 2000) [hereafter Armstrong, Norfolk], pp. 109-12.

${ }^{29}$ J. Schellekens, 'Illegitimate Fertility Decline in England, 1851-1911', Journal of Family History, xx (1995) [hereafter Schellekens, 'Illegitimate Fertility'], 373; Laslett, 'Introduction', p. 56; Armstrong, Norfolk, pp. 110-11; A. Blaikie, Illegitimacy, Sex and Society: North-east Scotland, 1750-1900 (Oxford, 1993) [hereafter Blaikie, Illegitimacy]; S. King, 'The Bastardy Prone Sub-Society Again: Bastards and their Fathers and Mothers in Lancashire, Wiltshire and Somerset, 1800-1840', in Illegitimacy [hereafter King, 'Bastardy'], pp. 81-2; A. Blaikie, E. Garrett and R. Davies, 'Migration, 
Living Strategies and Illegitimate Childbearing: a Comparison of Two Scottish Settings, 1871-1881', in Illegitimacy [hereafter Blaikie et al. 'Migration'], pp. 141-67.

${ }^{30}$ Laslett suggests urban levels were generally low; Adair found that levels in early modern provincial towns conformed overall to the national average, but were higher than rural levels in the south and lower than rural levels in the north, while London levels were remarkably low. For the later nineteenth century Hollingsworth emphasized the regional perspective over urban/rural contrasts, though again noted the low figures for London: Laslett, 'Introduction', pp. 41, 62-4; Adair, Courtship, pp. 190-223; T.H. Hollingsworth, 'Illegitimate Births and Marriage Rates in Great Britain 1841-1911', in Marriage and Remarriage in Populations in the Past, ed. J. Dupaquier et al. (1981) [hereafter Hollingsworth, 'Illegitimate Births'], p. 442. E. Shorter, J. Knodel and E. Van De Walle found no regular relationship for selected European countries in 1900, but also suggest illegitimacy ratios (and probably also rates) rose first in cities in the eighteenth century: 'The Decline of Non-Marital Fertility in Europe', Population Studies, xxv (1971) [hereafter Shorter et al., 'Decline'], 390-2.

${ }^{31}$ Laslett, 'Introduction', pp. 31-9; Hollingsworth, 'Illegitimate Births', 440-1.

${ }^{32}$ Adair, Courtship, pp. 36-47; King, 'Bastardy', p. 73. The data from the parish registers that underpinned analysis in The Population History of England required different degrees of adjustment over time to allow for the growing gap between birth and baptism, the growth of nonconformity and residual under-registration: E.A. Wrigley and R.S. Schofield, The Population History of England 1541-1871: a Reconstruction (London, 1981) [hereafter Wrigley and Schofield, Population History], Table 5.27, pp. 140-1. Adair discovered that some of the data used by Laslett failed to include all bastards: Courtship, pp. 48-9.

${ }^{33}$ Shorter et al., 'Decline', 379-80; Laslett, 'Introduction', p. 15; Adair, Courtship, pp. 25-6.

${ }^{34}$ Adair, Courtship, pp. 26-7; Laslett, 'Introduction', pp. 15-16.

${ }^{35}$ Blaikie, Illegitimacy; Reay, Microhistories; Robin, 'Colyton'.

${ }^{36}$ Laslett, 'Introduction'; Woods, Demography, Fig. 4.12, insert following p. 96, p. c.

${ }^{37}$ Bishop's Stortford, Great Berkhamsted, Hemel Hempstead, Hertford, Hitchin, St Albans, Tring,

Ware and Watford: BPP1852-3, lxxxv, Population Tables I, pp. cciv-ccvii. The close correspondence between the general fertility rate calculated from the census report and from the digitized CEBs 
(correlation coefficient 0.99 ) gives great confidence in the quality of the census transcription relied upon for the calculation of other fertility rates in this table.

${ }^{38}$ The ratio of single/widowed to married women aged 15-44 in Hertfordshire stood at 105 . For the straw industry RDs it was 113, for non-straw 98; for rural straw RDs it was 105 , for rural non-straw RDs 93; for urban RDs 115, for rural RDs 97.

${ }^{39}$ Laslett, 'Introduction', pp. 62-4; Eighth Annual Report of the Registrar General for Births, Deaths and Marriages (1849), pp. 74-80; Armstrong, Norfolk, pp. 106-112. These conclusions support those of Adair for pre-industrial southern England: Courtship, pp. 190-6.

${ }^{40}$ Laslett, 'Introduction', pp. 19-20; Armstrong, Norfolk, Table 5.1, p. 107. Laslett notes, however, that the 1840s and 1850s may have been exceptional in this respect: 'Introduction', p. 20. This much vaunted correlation is also questioned in Adair's regional analysis of pre-industrial England: Courtship, pp. 64-5.

${ }^{41}$ However, see below, p. 28.

${ }^{42}$ These are not registration districts (or SRDs) but groups of districts: Eighth Annual Report of the Registrar General of Births, Deaths and Marriages (1849), pp. 78-80; Fifteenth Annual Report of the Registrar General of Births, Deaths and Marriages (1855), p. vi.

${ }^{43}$ Laslett, 'Introduction', Table 1.6, pp. 34-5.

${ }^{44}$ I am very grateful to Leigh Shaw-Taylor of the Cambridge Group for the History of Population and Social Structure for providing access to the parish register data for 1813-20.

${ }^{45}$ Figures for employment in 1891 in the Harpenden RD have been calculated from the CEBs.

${ }^{46}$ Laslett's calculations produce ratios of 51 for $1810-14,46$ for $1815-19$ and 55 for $1820-24$ :

'Introduction', Table 1.1(a), pp. 14-15. The differences may partly reflect the long-standing disparity between the north and west and the south: Adair, Courtship, pp. 48-91.

${ }^{47}$ Eighth Annual Report of the Registrar General, p. 73.

${ }^{48}$ The correlation coefficient between the data for $1813-20$ and $1847-5$ is just 0.02 ; the rank correlation between the two series is marginally negative at -0.18 .

${ }^{49}$ Goose, 'Cottage Industry'. 
${ }^{50}$ An alternative explanation would be that the negative rank correlation between $1813-20$ and 1842/5 indicates the parish register data are seriously flawed, but there is no internal evidence to suggest that this was generally the case. Of course, it is impossible to prove beyond doubt a causal relationship between straw plait and illegitimacy, particularly as no occupational information for women is available, but the data supports this hypothesis.

${ }^{51}$ BPP 1843, xiv, Second Report of the Children's Employment Commission, Appendix, p. A11.

${ }^{52}$ BPP 1864, xxii, Second Report of the Children's Employment Commission (1862) p. xl.

${ }^{53}$ Report of the Royal Commission on the Employment of Children, Young Persons and Women in Agriculture (1867), BPP 1867-68, xvii, Appendix, Part I, p. 135.

${ }^{54}$ Ibid., Appendix, Part II, pp. 466, 515.

${ }^{55}$ H. Evershed, 'Agriculture of Hertfordshire', Journal of the Royal Agricultural Society of England, xxv (1864), 315 .

${ }^{56}$ Two more were children of lodgers and hence still with their parents.

${ }^{57}$ M. Anderson, 'Household Structure and the Industrial Revolution: Mid-Century Preston in Comparative Perspective', in Household and Family in Past Time, ed. P. Laslett and R. Wall (Cambridge, 1972), p. 233.

${ }^{58}$ N. Goose, 'Poverty, Old Age and Gender in Nineteenth-Century England: the Case of Hertfordshire', Continuity \& Change, xx, (2005) [hereafter Goose, 'Poverty'], pp. 1-34.

${ }^{59}$ Laslett, Introduction', pp. 34,39 . Hertfordshire actually held its position at $24^{\text {th }}$ between $1870-72$ and $1890-92$, falling to $37^{\text {th }}$ only by $1900-02$, but as there were ten counties whose illegitimacy rate in 1900-02 stood less that one percentage point above that in Hertfordshire, this change in rank order was less dramatic than it might at first appear.

${ }^{60}$ Plaiting and rural bonnet sewing was usually conducted within a domestic context. In St Albans, however, there were employment opportunities in small hat-making manufactories as well as in the domestic context found in the plaiting villages. Here illegitimacy rates stood above the county average, but they were not dissimilar to the levels found in towns such as Ware and Bishop's Stortford, where no such employment existed, and stood below the level in Hitchin, where plaiting rather than hat making was overwhelmingly dominant. 
${ }^{61}$ Calculations have been made at parish level from the 1851 CEBs and aggregated into straw and nonstraw and urban/rural components for each of these measures.

${ }^{62}$ See Table 1, above. Laslett, 'Introduction', pp. 53-9. The general inverse relationship between nuptiality and illegitimacy holds for straw areas in Hertfordshire (particularly rural), but not for Hertfordshire towns.

${ }^{63}$ Laslett, 'Introduction', p. 56; Schellekens, 'Illegitimate Fertility', 367, 373; Adair, Courtship, pp. 203-23.

${ }^{64}$ Again contemporaries can be found who were only too willing to brand servants as promiscuous and untrustworthy, Henry Mayhew among them, while Mrs Beeton remarked that 'It is the custom of “Society” to abuse its servants...': I. Beeton, Mrs Beeton's Book of Household Management (reprinted Chancellor Press, 1985, $1^{\text {st }}$ published 1859-61), p. 961; P. Horn, The Rise and Fall of the Victorian Servant (Stroud, 1995, $1^{\text {st }}$ published 1975), pp. 152-5; J.R.Gillis, For Better, For Worse; British Marriages 1600 to the Present (Oxford, 1985) [hereafter, Gillis, For Better, For Worse], p. 244. For similar recent thoughts on domestic servants in Skye see Blaikie et al. 'Migration', p. 167. In Elizabeth Gaskell's Cranford, Miss Matilda's servant Fanny was forbidden by the articles of her engagement to have 'followers': Cranford, chapter III.

${ }^{65}$ Wrigley and Schofield, Population History, pp. 229-31, 427-8, 529; Woods, Population, p. 17.

Extant reconstitutions show age of marriage rising in some parishes $1800-24 / 1825-47$, falling in others: E.A. Wrigley, R.S. Davies, J.E. Oeppen and R.S. Schofield, English Population History from Family Reconstitution 1580-1837 (Cambridge, 1997), pp. 186-7. The possibility of under-registration in the parish register data, and the fact that only individual and potentially exceptional years are represented for $1830,1840,1842$ and 1845 , must be borne in mind.

${ }^{66}$ A. Kussmaul, Servants in Husbandry in Early Modern England (Cambridge, 1981), Appendix 8, pp. 170-1; KD.M. Snell, Annals of the Labouring Poor: Social Change and Agrarian England 1660-1900 (Cambridge, 1985), Table 2.1, p. 96; A. Armstrong, Farmworkers in England and Wales: a Social and Economic History (Ames, Iowa and London, 1988), pp. 61-87.

${ }^{67}$ The impact of harvest failure is reflected in a sharp rise in admissions to Hatfield Union Workhouse in the calendar years 1842 and 1847: Hertfordshire Archives and Local Studies, BG/HAT 41. 
${ }^{68}$ Goose, 'Poverty'; K. Williams, From Pauperism to Poverty (1981) [hereafter Williams, Pauperism], pp. 68-75; W. Apfel and P. Dunkley, 'English Rural Society and the New Poor Law, 1834-47', Social History, x (1985), 39-48; S. Williams, 'Earnings, Poor Relief and the Economy of Makeshifts:

Bedfordshire in the Early Years of the New Poor Law', Rural History, xvi (2005), 29-32; Statutes of the Realm, 4 \& 5 William I, c. 76, clauses LXIX-LXXVI; U.R.Q. Henriques, 'Bastardy and the New Poor Law', Past and Present, xxxvii (1967) [hereafter Henriques, 'Bastardy'], 103-29; T. Nutt, 'The Paradox and Problems of Illegitimate Paternity in Old Poor Law Essex', in Illegitimacy, pp. 104-6. Illegitimacy ratios doubled in Terling and Bottesford after the 1834 Poor Law Amendment Act, though not in Colyton: D. Levine, Family Formation in an Age of Nascent Capitalism (1977), p. 138. Levine's 'courtship frustrated' model is similar to that proposed here, and it is notable that he identifies a number of years during the 'hungry forties' when illegitimacy levels were particularly high: 1840, 1842, 1846, 1847 and 1848: ibid., pp. 127-52.

${ }^{69}$ Henriques, 'Bastardy', 121-2; see also Sixth Annual Report of the Registrar General for Births, Deaths and Marriages (London, 1845), p. 432. In the year following the passage of the Act low numbers of affiliations were reported to the House of Commons in most counties, with exceptions in some counties and jurisdictions, while the Colchester (Essex), Bishops Castle (Shropshire), Southwold (Suffolk) town clerks, and the clerk of the peace for Kesteven, Lincolnshire, all noted cases had failed due to lack of corroborative evidence: BPP 1835, xlvii, pp. 455-468; BPP 1837-8, xxxviii, pp. 413-40. The 1831 and 1840 data require closer scrutiny at county level.

${ }^{70}$ M.D. Stevens, 'The "Characteristics” of Crime in Hertfordshire c.1825-50', unpublished MA thesis, University of Hertfordshire, 2003, pp. 26, 32. For high rural crime generally in the 1840s and early 1850s see D. Jones, 'Rural Crime and Protest', in The Victorian Countryside, ed. G. Mingay (2 Vols., 1981), ii, pp. 571-3.

${ }^{71}$ Gillis claims the decline began in the 1840s, but while illegitimacy ratios declined from 1845-9, illegitimacy rates only fell from 1861-5: Gillis, For Better, For Worse, p. 237; Laslett, 'Introduction', Table 1.1(c), p. 17.

${ }^{72}$ Williams, Pauperism, pp. 91-135; M. MacKinnon, 'English Poor Law Policy and the Crusade Against Outrelief’, Journal of Economic History, xlvii (1987), 603-25. 
${ }^{73}$ Statutes of the Realm, 7 \& 8 Victoria c. 101, cl. I-IX; amended to allow women to give evidence on appeal: BPP 1845, i, pp. 147-82; 35 \& 36 Victoria c. 65; Henriques, 'Bastardy', 119-20; Gillis, For Better, For Worse, pp. 238-9.

${ }^{74}$ L.A. Tilly, J.W. Scott and M. Cohen, 'Women's Work and European Fertility Patterns', Journal of Interdisciplinary History, vi (1976), 474-5. 